\title{
Bridging the gaps: atomic simulation of macromolecular environment brings together protein docking, interaction kinetics and the crowding effects
}

Xiaofan F Li , lain H Moal, Paul A Bates

From Sixth International Society for Computational Biology (ISCB) Student Council Symposium

Boston, MA, USA. 9 July 2010

\section{Background}

Cellular structures and functions rely on a complex network of regulated protein interactions, which are further based on complex molecular binding mechanisms. Three key questions are usually asked: a) how does a protein find its partner, b) at what rate do they interact and c) how they achieve the previous 2 goals in vivo. While these questions are usually studied in isolation, we believe that unique observations will be made by carrying out holistic investigation of the three problems under one roof, bringing together molecular docking, interaction kinetics and macromolecular crowding.

\section{Results}

We have developed a computational package capable of simulating a crowded macromolecular environment, in
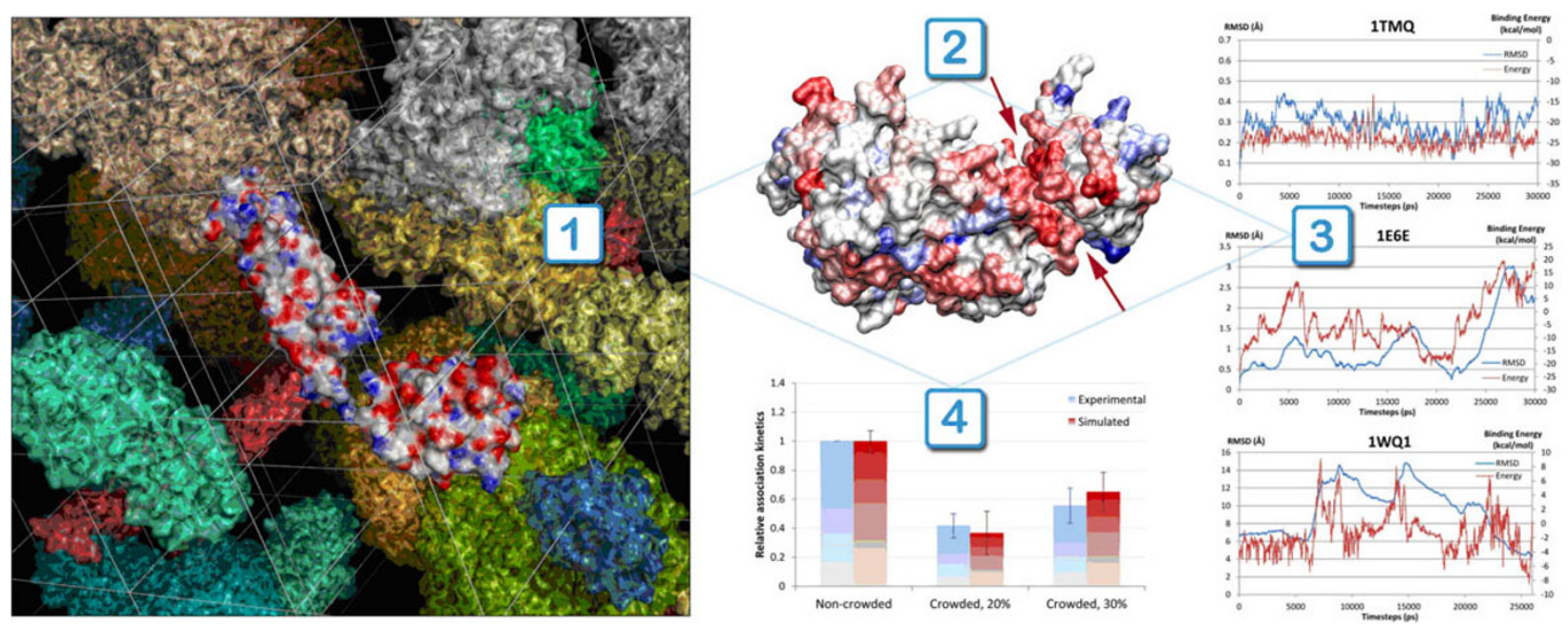

Figure 1 Under one roof: through crowded simulation (1), we are able to investigate pairwise docking (2), time-course information of encounter complexes (3) and the influences to protein kinetics by macromolecular crowding (4) at the same time and in the same interaction environment. Adapted from Ref [1] and a manuscript to submit.

* Correspondence: Xiaofan.Li@cancer.org.uk

Biomolecular Modelling Laboratory, Cancer Research UK London Research

Institute, 44 Lincoln's Inn Fields, London, WC2A 3PX, UK 
which proteins are modelled as full-atom parameterised rigid bodies. It is for the first time that specific proteinprotein interactions can be investigated in a multimacromolecular environment where all simulated bodies bear the same atomic resolution and forcefield parameters. It is also for the first time that the association rate constants, kon, can be scored by retention time of specific encounter complexes formed during the simulation and correlate with those experimentally determined. Calibrated on the experimentally determined kon in noncrowded and crowded environments, we revealed the possible molecular binding mechanisms and predicted the influence on such mechanisms from environmental crowders, of which ambient electrostatic interactions were shown to play an important part. Figure 1.

\section{Conclusion}

Our simulation effectively bridges the gap between structural studies of individual macromolecular complexes and their kinetic behaviour in a physiologically crowded condition. Potentially, this offers further connection to systemic approaches of studying regulatory network kinetics, as well as the enhancement of our ability to probe, manipulate and engineer molecular interactions in a simulated, but more realistic cellular environment.

Published: 7 December 2010

\section{Reference}

1. Li XF*, Moal I*, Bates PA: Detection and refinement of encounter complexes for protein-protein docking: taking account of macromolecular crowding. Proteins 2010.

doi:10.1186/1471-2105-11-S10-O2

Cite this article as: Li et al:: Bridging the gaps: atomic simulation of macromolecular environment brings together protein docking, interaction kinetics and the crowding effects. BMC Bioinformatics 201011 (Suppl 10):O2.
Submit your next manuscript to BioMed Central and take full advantage of:

- Convenient online submission

- Thorough peer review

- No space constraints or color figure charges

- Immediate publication on acceptance

- Inclusion in PubMed, CAS, Scopus and Google Scholar

- Research which is freely available for redistribution

Submit your manuscript at www.biomedcentral.com/submit 